\title{
Authoritarian Criminology and Racist Statecraft: Rationalizations for Racial Profiling, Carding and Legibilizing the Herd
}

\author{
Tamari Kitossa $a^{1,2}$
}

\begin{abstract}
This essay is an expose of authoritarian criminologists' neutralizing techniques that justify the technologies of racist statecraft: racial profiling and 'carding'. Principally focused on Canada and the US, the essay challenges the claims of authoritarian criminologists that the supposed ontological reality of crime refutes commissioned reports, case law and obiter dicta, government reports and scholarly research affirming racial profiling and carding. Assuming that statecraft is a racket in the purest sense, and, rooted in the epistemic conceptions of abolitionism, anti-criminology and countercolonialism, the essay turns the claims authoritarian criminologists hold to be true back onto criminology to see what account it provides for itself. From humanistic viewpoint, the results are found wanting. Following the path worn by Hannah Arendt, I show that in taking the effects of racial profiling and the legibilizing of carding as evidence of 'crime's' ontological reality, authoritarian criminologists are ethically and morally irresponsible in the exercise of judgment to the truth of statecraft's aspiration to govern through 'crime'.
\end{abstract}

Keywords: administrative-authoritarian criminology, racial profiling, carding, statecraft, legibility, colonialism, racism.

\footnotetext{
${ }^{1}$ Sociology Department, Brock University, Ontario, Canada

${ }^{2}$ The author wishes to thank Biko Agozino, Christopher J. Williams, Wesley Crichlow, Antje Deckert and the three confidential reviewers for helpful comments at various stages of this essay.
} 
[I]f the designing of the future and the proclamation of readymade solutions for all time is not our affair, then we realize all the more clearly what we have to do accomplish in the present - I am speaking of a ruthless criticism of everything existing, ruthless in two senses: The criticism must not be afraid of its own conclusions, nor of conflict with the powers that be [italics in original].

Karl Marx

[T]he problem of generating knowledge and protecting knowledge is a problem in politics, and, conversely the problem of political order always involves solutions to the problem of knowledge.

Stephen Shapin and Simon Schaffer

Most social science is expressly and unconsciously bound by state boundaries, categories that are reproduced within institutionally sanctioned academic specializations [...]. The problem endemic to the social sciences [is] [...] the difficulty of thinking outside the conceptual and material grasp of the modern state.

Itty Abraham and William van Schendel

The intellectual has to walk around, has to have the space in which to stand and talk back to authority, since unquestioning subservience to authority in today's world is one of the greatest threats to an active, and moral, intellectual life.

\section{Edward Said}

\section{Introduction}

In contemporary neo-liberal-colonialist social formations, racial profiling and 'carding' are mutually reinforcing necropolitical technologies of racist statecraft. As such, both are consistent with aspects of Foucault's conception of 'bio-politics' (1990) and in full accord with Mbembe's thesis of necropolitics (2003). As evidence of statecraft with the intent to make citizen-subjects "legible" and therefore controllable (Scott, 1998), the 
practice of racial profiling and the technology of 'carding' enables the leaders and operatives of the criminal industrial complex to catalogue, commodify, discipline, imprison, manage, surveil and, ultimately, kill disvalued populations. Jonathan Simon (2006) has called this project of domestic management "governing through crime". This is effectively the manufacture of a domestic enemy to generate fear which induces citizens to clamour to give up rights which the state eagerly takes on the condition of granting its 'protection' (Tilly, 1985). To this end, racial profiling is the critical assertion that on the weight of qualitative and quantitative evidence, negative racialization is the presumptive logic guiding the coercive and in/security industrial complexes criminalization and punishment of African descendants, Indigenous peoples and other people 'of colour' (Willis-Esquida, 2007). As a mode of social control, racial profiling has its origins in the blanket of capitalist exploitation that overlays the historical development of criminalization inherent to apartheid, colonialism and slavery. Skin colour, dress, hairstyles, tattoos and other markers of negative racialization worked up by the cultural ideology of the socially dominant group signify the forms of racial difference that are presumed to manifest 'criminality', and hence super-saturate surveillance by the police and socially dominant members of the public.

'Carding', a logical extension of racial profiling, is when - under the pretext of 'random' stops of cyclists, motorists, pedestrians and shoppers the police make citizen-subjects legible through entering their biographical, personality disposition and biometric and genetic particularities details into a police database for the precognitive and pre-emptive management of criminality. ${ }^{1}$ Whereas apartheid, colonialism and slavery each systematized through policing and punishment technologies of fingerprinting, passes and writs of permission, contemporary neoliberalism uses 'crime' as an opportunity to fulfil the object of statecraft by the same means. Racial profiling and carding, though directed at socially disvalued groups, makes all citizen's legible for purposes of social control. Through persuading all citizen-subjects, for 'their own safety', to accept submission (because consent is not an option) to searches, seizures and biographic databasing, racial profiling and 'carding' are pretexts for managing the whole 'herd'.

Rooted in counter-colonial, anti-criminology and abolitionist epistemology (Agozino, 2003; Christie, 2004; Cohen, 2007; Deckert, 2014; Hulsman, 1986; Kitossa, 2014; Lynch, 2000; Mathiesen, 1990; Saleh- 
Hanna, 2015; Tauri, 2012, 2014), my method of exposition is to turn the claims of authoritarian criminologists back onto criminology itself to see what account it provides for itself. To the extent that criminology has yet to tell the truth about its incapacity and incompetence to determine where in human beings or in their social environment the causes of crime are to be found or what policies can effectively control/reduce 'crime', I aim to show that in defence of racial profiling and 'carding' authoritarian criminologists are ideologues of statecraft.

What I argue in this essay, then, is that authoritarian criminologists' defence of racial profiling and carding is as much calculated to harm the interests of Indigenous peoples, African descendants and other people 'of colour' as much as to legitimate the open yet ideologically hidden dynamic of population management through the racialization of 'crime control'. I outline seven strategies of racial profiling and carding legitimation by authoritarian criminologists and discuss the social implications. But before arriving at that destination, I prepare fellow travellers with an account of statecraft and authoritarian criminologists' relationship to it. Following this brief exposition, I move on to offer evidence of racial profiling, carding and racial discrimination contrary to claims of authoritarian criminologists. I then outline the aforementioned seven neutralization techniques followed by discussion and conclusion.

\section{Statecraft and Authoritarian Criminologists}

Is it controversial and inaccurate to assert with any measure of confidence that in its disproportionality and disparate impact on African descendants, Indigenous peoples and other people 'of colour' that racial profiling and carding are racist tools of neo-liberal-colonialist statecraft? At one level, in front of answering that question is to think about the taken-for-granted epistemic and normative assumptions that make necropolitical statecraft possible. Meaning: 'crime' in and of itself must be refuted as having any ontological reality and, therefore, any validity beyond the instrumentalism of statecraft (Cohen, 2007; Hulsman, 1986). In another way, what is obviously at stake in the question is whether there is consonance between the (ritualistic) ideals of formal equality and political practice. Thus, given that the normative foundation of law and its enforcement in liberal democracies is predicated upon sustaining the ruling relations of ableism, capitalism, colonialism, hetero-patriarchy and white supremacy (D. 
Roberts, 1993), are racist outcomes not to be anticipated? If this is so, in what relation do authoritarian criminologists stand to methods of statecraft such as racial profiling and carding?

Alternatively, if one accepts both consensualism and the thesis that the state-as-Leviathan is a neutral arbiter preventing a war of all against all, as do authoritarian criminologists, then three propositions follow. First, that what appears to be discrimination and disproportionality are not so at all but rather an empirical measure of the determined will of some to break the law. Measured against the performance of acceptable and definable 'conduct norms', crime and negative racialization map each other in predetermined ways. That being so, determined will 2 arises from one, all or some combination of the 'facts' of biology, culture, psychology and socioeconomic status. In fine, some racial groups are more criminal and others less. Second, even if disproportionality arises from racial bias, the harmfulness caused by the criminogenicity of the racial Other justifies White personal avoidance and proactive state repression. Finally, since it is assumed that because racial disproportionality is evidence of the determinism and propensity of especially Black people to break the law, thereby making discriminatory enforcement a necessary evil in the maintenance of order, the values of those holding this position are presumably objective, neutral and untainted by political interests. Who are these people who make the mundane doing of evil itself conceptually mundane and what are its implications for criminological theory? These are not simply questions of intellectual practice, they are also questions of identity, positionality and power.

'These people' are authoritarian criminologists (Agozino, 2010; Kitossa, 2014; Tauri, 2012). They are to be found among a highly influential but small subset of criminologists in Europe and its far-flung White colonial offshoots: Australia, Aotearoa/New Zealand, Canada, Israel, South Africa and the USA. They are found among the ranks of the tertiary professoriate, think tank fellows and state ministries for the administration of the criminal law. As "defenders of [the extant social] order" (Schwendinger \& Schwendinger, 1970) they are connected to statecraft in concrete ways as quasi-state functionaries well-connected to coercive bureaucracies through the granting system and in the criminal industrial complex as consultants. They often receive hefty government contracts, are awarded outsized scholarly research grants, are accorded status and 
prestige and are recipients of comfortable stipends from conservative think tanks.

As regards racism and criminalization, they uniformly assert that racism in the criminal legal system, especially in policing, is unsubstantiated, 'scientifically' imprecise and that claims of racial profiling and discrimination in the criminal industrial complex are motivated by anti-police dogmas and Left-wing ideology (Gabor, 2004, 1994; Gold, 2003; Levin, 1992; MacDonald, 2001, 2015a, 2015b; Melchers, 2003, 2006; Roberts, 1994, 2003). Of racial profiling they assert the following: it is a discourse driven by moral entrepreneurialism of the liberal press; it is accepted and propagated by misguided, self-serving and 'politically correct' politicians, liberal judges, departments and ministries of 'justice'; it is fostered in academia by a too permissive and Left-leaning professoriate, keen to cash in on the 'cottage industry' of racial profiling surveying; and that claims of racial profiling and bias in 'carding' are simultaneously a cover to avoid public policy attention to the reality of 'Black-on-Black' crime and Indigenous 'criminality' - of course with the salutary effect of promoting undeterred criminality by socially disvalued persons and groups.

I am less interested to debunk these claims than to demonstrate how, in the hands of authoritarian criminologists, they serve the use of 'crime' as a neo/colonialist tool to justify racist statecraft. In doing so, I want to show that the rationalizing claims for unfettered police discretion, acceptance of the 'facts' about race and crime generated from racial profiling and 'carding' and an uncritical stance toward the state includes the assertions that: race (i.e., non-Whiteness) is a proxy for 'criminality' (i.e., illicit drug dealing and interpersonal violence), and that 'criminals' justify their behaviour through neutralization techniques. Given that, as noted by John Hepburn (1978), "Political society is built on a foundation of repressive force" (p. 72), my tack is to expose the neutralization techniques of authoritarian criminologists as a technology of totalitarian ${ }^{3}$ statecraft $^{2}$ and to demystify the social-contractarian 'right' of the state to bludgeon citizen-subjects into obedience when/where persuasion fails (Nicolaus, 1969; Schwendinger \& Schwendinger, 1970). In very explicit ways, I demonstrate that from the authoritarian criminologist's standpoint, 'crime' is a rhetoric whose practical function is to enable domestic pacification of the citizen-herd by economic, military and political elites - in short, 
statecraft is a protection racket, a veritable regime of violence consisting of extortion, extraction, deprivation, lies, threat and the breaking of bodies (Galtung, 1969; Lundberg, 1973; Mills, 2000; Tilly, 1985). It may be regarded as a harsh and even unwarranted judgment of authoritarian criminologists that they are 'little Eichman's' whose task it is to endorse totalitarianism and inure citizen-subjects to the totalitarianism under which they exist (see Arendt, 2003), ${ }^{4}$ but this is exactly the point I assert. What does one call those whose social function it is to justify statecraft's containment and legibilizing of citizen-subjects through racial profiling and 'carding'? Are we not beyond the point that criminologists in general and authoritarian criminologists in particular "have an extraordinary potential for being dangerous people" (Christie, 2004, p. 95); are, in fact, so? Is not normalizing the toxicity of statecraft the raison detre of criminology (Kitossa, in review)?

\section{Do Racial Profiling and Racial Bias Existin Policing and the Criminal Legal System?}

Is there evidence that at best affirms or at least infers racial profiling, carding and racism in the criminal legal system? The answer to this question depends on whom it is asked, what is considered evidence and the method for its collection and the stakes in the issue. Since I cannot possibly present the sum of all affirming and inferential evidence, I will proceed phenomenologically, treating a narrow range of evidence presented as representative. I will, to this end, present evidence gathered from a variety of methodological approaches. Because by now it is not a secret to the reader that I regard 'crime' as having no other content besides being a focal point of moral outrage, ideologically for the state to justify the ongoing racket of statecraft, I must be clear that I am not personally interested to endorse the evidence confirming racial profiling and racism in the criminal legal apparatus. I am rather interested in authoritarian criminologists' scepticism requiring absolute knowledge (to the exclusion of inferential knowledge), methodological absolutism and the pretension of disinterestedness. All of this despite the first principle that colonialism, imperialism and slavery occurred and now burden the living with the dead weight of their history. So, while it cannot seriously be doubted that moonshine is a reflection of the atomic chemistry of the sun, a) why is there doubt that racial profiling and 'carding' do not reflect racist statecraft 
and b) why, if racial profiling and 'carding' are accepted as existing, do some authoritarian criminologists think that while these are evils they are also socially necessary?

This brief excursus must begin historically, quite specifically at the historical juncture in which criminology was established and which it has yet to come to grips with: colonialism, capitalism, imperialism and slavery (Agozino, 2003; Cohen, 2007; Staples, 1975). It must be noted that in addition to its impoverishment for want of theoretical engagement with culture, political economy and the state (Cohen, 2007; Ferrell et al., 2004; Hillyard \& Tombs, 2004), criminology is constitutively amnesic (Hirschi, 1993). Always in the present, yet relying on tired tropes, criminology is strategically amnesic. Criminology especially has no capacity to deal with memories of colonialism, genocide and slavery - to which it was either indifferent or aided and abetted by its complicity with racist statecraft.

To this end, racial profiling, a term which did not so much as register a blip in the media and scholastic literature, came into prominence in the early 2000s, particularly in the US where the DEA formalized race as a trait in its interdiction profiles through the 1990s Operation Pipeline. Newspapers detailed blatant abuses of citizen-subjects legal rights, not limited to civil asset forfeiture, which amounted to bold-faced robbery, and a series of court challenges. In the US, the basis for popularizing racial profiling centred on the $4^{\text {th }}$ (search and seizure) and 14th (equal rights) Amendments to the US Constitution and, in Canada, on Charter Sections 7 through to 9 (Gross, 2007; Tanovich, 2006, 2004).

As noted by Cynthia Willis-Esqueda (2007), the practice awaited the discovery of nomenclature. In asserting that "racial profiling as a means for law enforcement to wield power against individuals of colour with irrelevant or no evidence for doing so" (p. 75), Willis-Esqueda deftly side-steps what authoritarian criminologists take for granted - that the criminal law is about power, not about harm. The consequence of delinking the term racial profiling from the presumption of harm is that we are free to identify how discretionary enforcement occurs under the bald violence of settler colonialism, plantation slavery and the bloody dispossession of Indigenous peoples. It can be said with utmost confidence that, aside for the brief time when whiteness was being formalized as a social identity, Europeans never endured the vicissitude and fungibility of slavery, scalping and harvesting of hands and feet, medical experimentation, forced dispossession, 
biological warfare, child apprehensions, mass rape, bantustans/reservations, genocide and ascribed intergenerational calumny because of race (Daschuk, 2013; Davis, 2014; Davis, 2001; Diamond, 1997; Du Bois, 1935; Fanon, 1967; Hochschild, 1998; Rodney, 1982; Stannard, 1994; Washington, 2006; Willhelm, 1971). And all of this sanctified by the 'rule of law'!

Throughout the European colonial dominions of the Americas, African descendants, Indigenous peoples and people 'of colour' were not only marked out as prospective criminals, but their subordinate status required a regime of legal restraints, material practices, surveillance and techniques for legibility - passes and writs of permission and freedom. This fact was most explicitly seen with transatlantic plantation slavery in the Americas. Most notably in the US, the narratives of formerly enslaved persons - as well as those free-born persons such as Frederick Douglass, Harriet Jacobs and Solomon Northup among others - detail two originary facts of racist statecraft. Firstly, that chattel slavery developed a wellworked-out regime of slave catchers, the deputization of all White persons as adjunct police (sometimes on pain of punishment) and a culture of quotidian sadism (Hadden, 2001; Hartman, 1997; Hawkins \& Thomas, 1991). Viviane Saleh-Hanna (2016) notes that of consequence for colonialist/racist statecraft and relevant to the continuity of control and legibilizing practices,

[t]he criminal justice system and chattel slavery are flip sides of Western democracy's coin of capital. Each side of this coin foreshadows and constructs the other side of this coin, living in perpetual intersectionality and co-dependence. Chattel slavery and criminal justice are both at the beginning of this system, one and the same, haunting, replacing, reforming and rebirthing one other (para. 5; see also Kitossa, 2005; Muhammad, 2010).

Secondly, critical to maintaining this coercive regime was the soft strategy of racist statecraft - the legibilizing of African Americans through Black/slave codes and documentation attesting to their social status (free or enslaved) and 'rights' of movement beyond plantations and the property of their masters, or, in their own recognizance if free (Parenti, 2003; Stewart, 1998; Willis-Esqueda, 2007). 
Crucially for an understanding of how criminalization, racial profiling and 'carding' became essential tools of racist statecraft, it is vital to recognize that slavery was a massive regime of social confinement that made incarceration moot. Thus, as with transatlantic slavery which punished the innocent with social death (Agozino, 2003), the abolition of slavery was more rhetorical than actual because, in the US, Jim Crow, chain gangs and imprisonment became its new form. As noted by many scholars, principally arising from the habit of slavery and necessity caused by the technological and infrastructural underdevelopment of the South, African Americans moved within two decades after 1865 from about 2\% to 90\% of all prisoners (Alexander, 2010; Blackmon, 2009; Childs, 2015; Davis, 2003; McIntyre, 1993).

This historical context tells us that, as Freda Adler (1976) stated, when "'crime' is stripped of [its] ethical rationalizations and philosophical pretensions, a crime is anything that a group in power chooses to prohibit" (p. 155). Arising from the fundamental fact of racist statecraft, well over 100 years of scholarly inquiry beginning in the early twentieth century despite its commitment to determinism and positivism - left no doubt that the apparent race-crime link was produced as a matter of fact by the castelike operation of racial bias in policing, the courts and punishment (Bonger, [1915]1969; Du Bois, [1899]1967; Sellin, 1935; Sutherland \& Cressey, 1955). Statistics on so-called Black criminality were recognized as produced by the legal framing of human conduct and selective enforcement and punishment which reproduced extant social, economic and political relations. To this end William Ryan (1971) noted at the time of the ghetto rebellions that

[w]e must judge why we hire policemen by the evidence. Presumably we hire them to do what they, in fact, do: arrest black people and poor people. In functional terms, it would be hard to evade the conclusion that the major task we give to our police is to control potentially disruptive or troublesome groups in the population (p. 215-216).

That this alternative way of thinking about statistics on race, 'crime' and punishment did not become received wisdom owed much to the necessity of ideology propagated by the state's interpretation of the statistical measures for gauging the activities of its agents in selectively 
enforcing the law to maintain social order. Here one need only think of the nearly sacred status bestowed upon J. Edgar Hoover's innovation - the Uniform Crime Report. Critically though, because what is the concern of criminology (and the social 'sciences') is already determined by the interests of the state and the dominant culture, the determinism and positivism at the heart of criminology lend themselves to treating the results of state activity as confirmation of race as causation rather than the results of unequal enforcement and punishment (Brown, 2001; Cook \& Hudson, 1993; Covington, 1995; Gilroy, 1987; Mann, 1993, 1995; Reasons, 1974; Staples, 1975). There is a line of continuity from colonialism and slavery to the present social configuration.

Across Canada, the UK and the US, recognition of the historical depth of racial discrimination in the criminal legal system has led to efforts to document the scope and validity of racial profiling and 'carding'. The sheer bulk of material generated since around the early 2000s to the present is overwhelming, clearly beyond my stamina and ingenuity to digest it all. I, therefore, attend only to a very, very, thin sliver of conclusionary and inferential data, with which I am familiar, among social 'scientists' (Epp et al., 2009; Harcourt, 2006; Harris, 2003; Institute on Race and Justice, n.d.; Lamberth, 2006; Moreton-Robinson, 2009; Tanovich, 2006; Tator \& Henry, 2006; Hayle et al., 2016); human rights commissions (Equality Human Rights Commission, 2012; Nova Scotia Human Rights Commission, 2019; Ontario Human Rights Commission, 2017, 2018; Quebec Human Rights Commission, 2011); civil liberty groups (American Civil Liberties Union, 2009, 2013; British Columbia Civil Society, 2010); civil society and constitutional rights groups (CAPP, 2014; Center for Constitutional Rights, 2012); police forces and boards (Fearon $\&$ Farrell, 2019; Foster et al., 2016; Wortley, 2006); the courts (R. v. Dudhi, 2019 ONCA 665; R. v. Le, 2019, SCC 34); the press (Rankin, 2002; Rankin \& Winsa, 2013); and finally, both exposés by ex-cops (Juarez, 2004; Stamper, 2005) and matter-of-fact testimony by police officers to researchers (Satzwhich \& Shaffir, 2009). All these are explicit that the identities of Black, Indigenous peoples and people 'of colour' are strong cues for the presumption of 'criminality'.

This small sample of evidence either affirms or infers racial discrimination in policing. Indeed, the Ontario Human Rights Commission laments in its 2017 report that: 
The widespread nature of incidents of racial profiling, along with a growing body of case law and social science and legal research, confirm not only that racial profiling exists, but also that it is a broad concern shared by many Ontarians. Alarmingly, the experiences we heard were similar to the ones we heard when we did our [first] racial profiling inquiry back in 2003 (p. 6).

The depth of racial profiling and race-based carding in police culture and the way police officers go about enforcing the law is at this point regarded as irrefutable by the courts in a way that infers a wider social acknowledgement that racism in policing is not a question of a few bad apples'. Thus at Peart v. Peal Regional Police Services Board, Justice Doherty asserted it is now accepted by "the courts that racial profiling occurs and is a day-to-day reality in the lives of those minorities affected by it" (2006, para. 94). And finally, it must never be forgotten that Richard Nixon in launching his 'drug war' in the early 1970s was explicit about his intentions according to his henchman, John Erlichman (as cited in Baum, 2016):

The Nixon campaign in 1968, and the Nixon White House after that, had two enemies: the antiwar left and black people. You understand what I'm saying? We knew we couldn't make it illegal to be either against the war or black, but by getting the public to associate the hippies with marijuana and blacks with heroin, and then criminalizing both heavily, we could disrupt those communities. We could arrest their leaders, raid their homes, break up their meetings, and vilify them night after night on the evening news. Did we know we were lying about the drugs? Of course we did.

By any measure, the evidence demonstrating the state's use of race in policing is not seriously disputed. In much the same way that a reasonable person thinking about the Anthropocene must concede that fossil fuels are a bust and not a boon to continued human existence, reasonable persons are coming to conclude that racial profiling and racialized 'carding' are no longer a matter of debate. Why then, from 
authoritarian criminologists is there disparagement, highly stylized scepticism articulated through the rhetoric of science and, in some instances, where the evidence is accepted, its meaning depends on: a) deterministic ontological assertions regarding the objective reality of 'crime' and $b$ ) exonerations of racist statecraft? But aside from questions of theory, method and the philosophy of knowledge is the question of ethics. Given that the overwhelming bulk of what each person knows is known mediately rather than empirically and sensually, and that it is the business of expert communities to generate verifiable knowledge, even if it is inferential, is it an abdication of ethical responsibility to assert human-induced climate change is a 'Chinese hoax' any more than to say that racial profiling and racialized 'carding' does not occur because they are, at best, only inferential? Is it bad faith to claim that racist statecraft is justified because Black, Indigenous peoples and people 'of colour' are deterministically 'criminal' and White people must be protected from them?

Having demonstrated the allegiance of authoritarian criminologists as ideologues for necropolitical statecraft, I know present seven neutralization techniques of authoritarian criminologists for racial profiling and carding.

\section{Neutralization Technique One: Claims of Racism in Policing Undermine Public Safety}

Claims of racial profiling and the presumed unconstitutionality of 'carding' is a ploy intended to racially polarize policing, thereby undermining its credibility and the capacity for police officers to enforce the law (Gabor, 2004; Melchers, 2003, 2006; Mac Donald, 2001, 2015a, 2015b; Roberts, 2003). As a result, police are reluctant to enforce none but the most serious criminal offences for fear of being (unfairly) castigated as racists. To this effect in a paper commissioned by the RCMP's Research and Evaluation Branch, Ronald-Frans Melchers (2006) argues that claims of racial profiling threaten

to place justice into disrepute, [and make] [...] the work of ensuring public safety and enforcing the law more difficult when it involves members of visible minority communities and threatens to endanger the security of visible minority 
communities themselves by empowering criminals and criminal organizations in their midst (p. 2).

Because in the wake of the police murders of Michael Brown and Freddy Grey that lit the fuse to urban unrest, cops, Heather Mac Donald (2015a) claims, are afraid to undertake the "prime gauges of proactive enforcement": "summons for low-level, quality offences such as public urination". Police are, as a result, afraid to enforce all but very serious infractions. With 'crime rates rising', the result is that the "streets get mean".

\section{Neutralization Technique Two: Your Methods Are Flawed, Mine Are Not, Because We All Know 'Crime' Is Not Randomly Distributed}

Second, it is believed that research purporting to confirm racial bias in policing is dismissible on two grounds. Such studies are ostensibly cherrypicked, methodologically flawed and reliant on 'bulk anecdotes', which it is claimed cannot be 'scientifically' verified (Gold, 2003). From such 'flawed' studies, any conclusion ascertaining racial bias is believed to be inconclusive or misplaced (Melchers, 2004, 2006). If at all racial bias is conceded by authoritarian criminologists, it is presumably a result of the proverbial 'bad apples' rather than personal, institutional or systemic racism (see Gold, 2003; Melchers, 2004). It is relatedly argued that, if at all racial bias occurs, it is because "a handful of police officers may unfortunately and illegally be bigots" (2003, p. 393). Beyond a few rogue elements and 'bad apples', it is believed extant statistical methods lack the sophistication to actually determine whether racial profiling occurs or not. It is asserted time of day, how many kilometres driven or walked, whether a community is a 'high' or 'low' crime area, and, especially because there is a lack of credible "benchmarks" respecting the characteristics of persons stopped versus the general population are factors which must all also be considered. Beyond rogues and bad apples, "[i]t is simply implausible that actual profiling policies or practices on any basis, be it psychological or racial, would ever be officially adopted by a rationally behaving organization as an alternative to traditional, evidence-gathering, investigative practices" (Melchers, 2004, p. 361). So why then is there the perception racial profiling occurs? Paradoxically, Melchers (2004) continues, "[b]ecause so many organizations have indeed done so, despite 
overwhelming indications of the folly of such approaches" (p. 361). Besides all this, it is asserted that crime is not in any case random - thereby assuming a causal link between race and crime (Gabor, 1994; Mac Donald 2001; Melchers, 2004; 2006; see also Levin, 1992; Rocque \& Posick, 2017).

\section{Neutralization Technique Three: What Looks Like Racial Bias Is Mistaken For Good Policing}

Following from the justification that 'crime' is not randomly distributed and is therefore committed more by some racial groups than others, good police work often appears discriminatory to the uninformed (Gabor, 2004; Gold, 2003; Mac Donald, 2001; Melchers, 2006). Thus "whether or not racial profiling is officially sanctioned in an organization, the statistical results of police operations often look the same" (Melchers, 2004, p. 362). Especially in the area of narcotics arrests, charges and incarceration, it is argued that criticisms of the so-called war on drugs are an effort to conceal that racial "disparities in offending behaviours" are objectively real (Melchers, 2006, p. 76). In addition, it is believed that arrests for violent offences are disproportionately committed by African Canadians (Melchers, 2004, 2006) and African Americans (Levin, 1992; MacDonald, 2001, 2015a, 2015b), apparently confirming their greater propensity toward violence. Discretionary authority and heavy deployment where poor African Americans and African Canadians predominate, then, is presumed to be a nonissue and, in fact, a positive right of the state to do so. Because, notes Levin (1992), "[r]ace is an information-bearing trait" about actual and potential 'criminality', then "[t]he state's regular use of other informationbearing traits to prevent serious crime sets a precedent for state use of information supplied by race for the same purpose" (p. 8). Thus - while there may be harm to the civil rights of Black, Indigenous peoples and people 'of colour' for aggressive policing - the greater harm arises from not racially profiling and carding.

\section{Neutralization Technique Four: Racial Profiling Is Discourse Imported Into Canada From The US}

In Canada at least, racial profiling is an imported ideology from a racially divided United States of America (Gold, 2003; Melchers, 2004). The assumption is that gullible liberal White Canadians and sympathetic 
"visible minorities" make much ado about nothing in a country, like Canada, where, if racism exists, it is a rare event of isolated bigots (Gold, 2003; Melchers, 2004). Thus "[n]otwithstanding its growing acceptance in the courts, among the media and with the public, the evidentiary basis for allegations of 'racial profiling' is weak, often fabricated" (Melchers, 2006, p. 2). But it is especially "media sensationalism" driven by the Toronto Star's reporting that have popularized the term and have given "black', 'black identity' or 'African Canadians' of diverse cultural background and origin" (2006, p. 11) grist for the mill to make false accusations against a blameless and scapegoated police.

\section{Neutralization Technique Five: Claims Of Racial Profiling Is An Excuse For Criminals Not To Be Held Accountable}

Claims of racial profiling then, is the work of malcontents who seek to make "policing racial minority communities [...] more difficult by [...] [the] burden [of such an accusation] [...] that reduces [...] the safety of those same communities, already subject to high rates of victimization, in particularly violent victimization" (Melchers, 2004, p. 21). More than this, it is implied that in the post-9/11 US accusations of racial profiling are a well-orchestrated psychological tactic by 'criminals' (and Islamic?) "militants seeking to further the belief that these groups are so singled out" (Melchers, 2004, p. 12). By imputing bias to the police, it is asserted that the 'criminals' in high-crime groups can create greater opportunity to commit more crime (Levin, 1992; Mac Donald, 2001, 2015b; Melchers, 2006).

\section{Neutralization Technique Six: Your 'Science' Is Junk, But My 'Science' Is Science}

It is asserted that a distinction must be made between 'good' and 'junk' science in the study of racial bias in policing (Gold, 2003). It is here presumed that criminology is a value-free study of 'crime' causation, implying that criminologists are not a part of the social reality they study. As a result, human behaviour is determined and quantifiable as one would count molecules and that 'crime' is objectively real. Assuming criminology is a 'science', it is believed the cultural and/or racial factors of a person's identity are objective bases to determine criminality. Moreover, in relation 
to the presumption that crime is inscribed on the exploited classes and negatively racialized persons, police statistical reports are objective measures of 'criminality'. This positivistic orientation presumes the scientific method can be used unobtrusively to apprehend 'criminality' while measuring the effectiveness of police work. Should 'political categories' such as 'racial profiling' intervene in the objective apprehension of 'criminals' and the recording of 'crime', then and only then, is 'science' spoiled. As Ronald-Frans Melchers (2006) argues the term racial profiling is

[f]oremost a political term, it is not intended to provide an operational or empirical definition. It is used in everexpanding contexts and ways, eluding any evidentiary quality. Racial profiling is a presumption and an "unfalsifiable" claim. There are simply no circumstances in which it can be objectively rejected. Little of what is stated about racial profiling has, nor could have, any empirical basis [emphasis added] (p. 1).

What is needed are a) an agreed-upon definition and b) to determine whether bias exists or whether it is criminality being mistaken for 'good policing' through a dispassionate inquiry led by skilled social 'scientists' fully adept at statistics (Gabor, 1994, 2004; Roberts, 1994, 2003).

\section{Neutralization technique seven: Claims of racial profiling are a threat to social cohesion}

Finally, it is contended that since assertions of racial profiling have no scientific merit, has no basis in reality, and is a ploy to undermine law enforcement, it is a dangerous discourse. Ronald-Frans Melchers (2006) argues, "Racial profiling' beliefs are a threat to social cohesion and public safety. They drive a wedge between law enforcement officials and those who, for whatever reasons, come to think of themselves as their victims" (p. $1)$. 


\section{Discussion}

These seven rationalizing strategies for racial profiling and racialized 'carding' constitute the basis upon which administrative-authoritarian criminologists deploy their colonialist-racial logic in defence of facially neutral policing. As noted above, I will not rehearse the flaws in the positivist and statistical reasoning of authoritarian criminologists nor deconstruct the myth of 'scientific criminology', having done so elsewhere (Kitossa, 2014). Indeed, to do so would be to engage in an infinite regress of absurd logic. For example, if racial profiling is an 'unscientific' claim because it is 'unfalsifiable', how is the opposite claim that 'good policing' merely seems discriminatory any less unfalsifiable? What method of induction can be used to falsify one claim rooted in experiences of racism and the other - a purely moralistic defence of whatever tactics enforcers of the law deem essential to justify their existence? Clearly, the belief that there is no racism in the criminal legal system cannot be assuaged by evidence attesting to the opposite. So, to get out of this corner, we must meet authoritarian criminology head-on, on the mound from which it trumpets its 'scientific' credentials as the basis for its credibility: moral philosophy.

Let me begin with criminology itself. The data based on which authoritarian criminology makes judgments about policy cannot avoid the ways that police discretion is articulated in deeply biased ways. First, the law is a social construction whose power to regulate some behaviours while allowing others to pass as appropriate standards of conduct derives from both historical factors and the arbitrary decisions of political authority to treat as 'criminal' some conduct but not other (Glassbeek, 2012; Hepburn, 1978; Reiman \& Leighton, 2017). Second, the police 'data' used to paint a picture of moral disorder in society, and to justify their ever-ballooning budgets, are, in fact, a distortion of events deemed 'criminal' (Reiman \& Leighton, 2017).

Indeed, since there is always more 'criminality' than can be detected by official agents of morality, what is recorded as 'criminal facts' are in reality "official statistics [...] that tell us more about police behavior than about criminals" (Reiman \& Leighton, 2017, p. 120). Such a view is confirmed by the Ontario Chiefs of Police who stated: "Driving and drug offences [...] are enforcement driven" (Ontario Association of Chiefs of Police, 2001). Behind the euphemism of 'enforcement driven' are the 
mutually entwined facts of institutional policy, individual discretion and the secret society culture of policing. Clearly, within the context of institutional policy, to prosecute a so-called drug war, target 'problem offences' and 'incivilities' or 'high crime areas' relies on implicit individual and organizational biases and professional shorthands that depend on class, racial and other biases. Hence, noted the Harvard Law Review Association (1988, p. 1496),

the argument that police behavior is undistorted by racial discrimination flatly contradicts most studies, which reveal what many police officers freely admit: that police use race as an independently significant, if not determinative, factor in deciding whom to follow, detain, search, or arrest.

More deeply than the distorted image of 'crime' and 'criminals' presented by official statistics, and, even deeper than what 'crime statistics' tell us about the decisions of officers, police culture and police departments, such data tell public administrators that the police are, in fact, directing their attention at the 'appropriate' targets of the criminal law (Douglas, 1971; Ryan, 1971). Indeed, as the US Seventh Circuit Court gives chilling and eloquent testimony, the behaviour of the police is not to be judged by the standards to which other citizens are held. For example, in the civil trial of Deputy Sheriff Jeffrey Drinski for the 1993 killing of Konstantino Plakas in Indiana, Justices Cummings and Coffey argue as follows: "In this sense, the police officer always causes the trouble. But it is trouble which the police officer is sworn to cause, which society pays him to cause and which, if kept within constitutional limits, society praises the officer for causing" (Plakas v. Drinski, 1994). Absurd as it is, the judges' remarks are an objective recognition of the facts concerning a range of abuses in policing. Quite aside from the instance of the sadist John Burge and his underlings in Chicago (Guarino, 2013), the 2013 case in the Ontario Court of Appeal heard a case of police torturing a suspect to gain a confession. The officer accused of beating a confession out of the accused apologized for doing so claiming "it's part of my job" (R V. Singh). The court in this instance was incredulous but, nonetheless, did not punish the officer. 
Relatedly, drawing on a 2004 National Academy of Sciences report titled "Fairness and Effectiveness in Policing: The evidence", Jeffrey Reiman and Paul Leighton $(2017$, p. 14) call attention to the following:

a) there was weak or no evidence to support the effectiveness of a 'standard model' of policing that relied on 'arrests and the threat of punishment' to reduce crime

b) that the effects of increasing the number of police were 'ambiguous'

c) that rapid response 'has also not been shown to reduce crime'

d) that 'research does not provide strong support for the proposition that zero-tolerance policing reduced serious crime'

e) in some cities, intensive enforcement overall increased social disorder

f) community policing relying on general foot patrol and storefront offices have not been found to reduce crime

In the final analysis, the moral philosophy of the authoritarian criminology's defence of racial profiling and 'carding' is an uncritical assent to absolute authority. This is a matter that concerns where constitutional limits should be drawn, and, at what price. Contrary to the idea that seeking accountability for police abuses of power will undermine both the law and 'social cohesion', it is well-noted by Stanley Milgram (1974) and Philip Zimbardo (2008) that there is no greater threat to human beings than blind obedience to authority, especially in social formations with authoritarian tendencies. At $R \quad v$. Ferdinand, Justice LaForme of the Ontario Superior Court of Justice could well be speaking to administrativeauthoritarian criminologists:

One reasonable [...] impression that one could draw from the information sought on these 208 is that they could be a tool utilized for racial profiling [...]. If the manner in which these 208 cards are currently being used continues; there will be serious consequences ahead. They are but another means whereby subjective assessments based upon race - or some other irrelevant factor - can be used to mask discriminatory 
conduct. If this is someday made out - this court for one will not tolerate it. This kind of daily tracking of the whereabouts has an aspect to it that reminds me of former government regimes that I am certain all of us would prefer not to replicate.

Given the police will continue to use race as a key factor of its professional competence to detect crime, the judiciary admits that the court on racial profiling and 'carding' remains in session but the door on whether there is bias in the criminal legal system is closed.

\section{Conclusion}

As a 'science', criminology, especially in the hands of authoritarian criminologists, is utter fiction. It is, however, very real and serious in its commitment to totalitarian statecraft. What I have tried to show in this essay is that authoritarian criminologists are undeterred in their mysticism because the very substance of their enterprise is wholly dependent on what the state determines is harmful to the social order. The difficulty of thinking outside the predetermined conceptual box established by the state, that crime has an objective reality, leads authoritarian criminologists to shudder at the prospect of their own autonomy. This dependency, in turn, assures that a critique of the state's chief instrument of domestic repression, the police, remains inscrutable. In the enduring effects of settler colonialism and the after-life of slavery, authoritarian criminologists are secular clerics who take on the role and function of their predecessors - Inquisitors and Enlightenment philosophers - who sought, by collusion with statecraft, total control of the social herd. Racial profiling and carding are at once denied being rooted in settler colonialism, imperialism and slavery in large measure because these odious means of social vampirism, now manifest in the doctrine of 'neoliberalism', deflect general awareness from the state's aspiration to achieve and maintain 'public safety' through the full spectrum dominance of a police state. 


\section{References}

Abraham, I., \& van Schendel, W. (2005). Introduction. In W. van Schendel and I. Abraham (Eds.) Illicit flows and criminal things: States, borders, and the other side of globalization (pp.1-37). Indianapolis, IN: Indiana University Press.

American Civil Liberties Union. (2013). The war on marijuana in black and white. Available at https://www.aclu.org.

American Civil Liberties Union. (2009). The persistence of racial and ethnic profiling in the United States. Available at https://www.aclu.org.

Adler, F. (1985). Sisters in crime: The rise of the new female criminal. New York, NY: McGraw-Hill.

Agozino, B. (2010). Editorial: What is criminology? A control-freak discipline! African Journal of Criminology and Justice Studies, 4(1): i$\mathrm{xx}$.

Agozino, B. (2003). Counter-colonial criminology: A critique of imperialist reason. London, UK: Pluto Press.

Alexander, M. (2010). The new Jim Crow: Mass incarceration in the age of colorblindness. New York, NY: The New Press.

Ani, M. (1994). Yurugu: An African centered critique of European cultural thought and behavior. Trenton, NJ: African World Press.

Arendt, H. (2003). Responsibility and judgment. New York, NY: Schocken Books.

Arendt, H. (1970). On violence. New York, NY: Harvest.

Aristotle (1958). The politics of Aristotle (Trans. E. Barker). New York, NY: Oxford University Press.

Baum, D. (2016). Legalize it all: How to win the war on drugs. Harpers Magazine. Available at https://harpers.org.

Bauman, Z. (2004). Wasted lives: Modernity and its outcasts. Malden, MA: Polity.

Bonger, W. (1969). Race and crime. Montclair, NJ: Patterson Smith.

Blackmon, D. A. (2009). Slavery by another name: The re-enslavement of Black Americans from the Civil War to World War II. New York, NY: Anchor Books.

British Columbia Civil Society. (2010). Racial profiling. Available at https://bccla.org.

Brown, M. (2001). Race, science and the construction of native criminality in colonial India. Theoretical Criminology, 5(3), 345-368. 
CAPP (2014). "This issue has been with us for ages": A community-based assessment of police contact carding in 31 division. Available at https://exchange.youthrex.com.

Center for Constitutional Rights (2012). Stop and frisk: The human impact: The stories behind the numbers, the effects on our communities. Available at https://ccrjustice.org.

Childs, D. (2015). Slaves of the state: Black incarceration from the chain gang to the penitentiary. Minneapolis, MN: University of Minnesota Press.

Christie, N. (2004). A suitable amount of crime. New York, NY: Routledge.

Cockburn, A., \& St. Clair, J. (1998). Whiteout: The CIA, drugs and the Press. New York, NY: Verso.

Cohen, S. (2007). Against criminology. London, UK: Transaction Publishers.

Cook, D., \& Hudson, B. (Eds.) (1993). Racism and criminology. London, UK: Sage.

Covington, J. (1995). Racial classification in criminology: The reproduction of racialized crime. Sociological Forum, 10(4): 547-568.

Daschuk, J. (2013). Clearing the plains: Disease, politics of starvation, and the loss of Aboriginal life. Regina, SK: University of Regina Press.

Davis, A. (2003). Are prisons obsolete. New York, NY: Seven Stories Press.

Davis, D. (2014). The problem of slavery in the age of emancipation. New York, NY: Alfred A. Knopf.

Davis, M. (2007). Planet of slums. London, UK: Verso.

Davis, M. (2001). Late Victorian holocausts: El Niño famines and the making of the third world. London, UK: Verso.

Deckert, A. (2014). Neo-colonial criminology: Quantifying silence. African Journal of Criminology and Justice Studies, 8(1), 39-60.

Diamond, J. (1997). Guns, germs and steel: The fates of human societies. London, UK: W. W. Norton and Company.

Du Bois, W. E. B. (1967). The Philadelphia negro: A social study. New York, NY: Benjamin Bloom.

Du Bois, W. E. B. (1935). Black reconstruction: An essay toward a history of the part which Black folk played in the attempt to reconstruct democracy in America, 1860-1880. New York, NY: Russell \& Russell.

Epp, C. E., Maynard-Moody, S., \& Haider-Markel, D. (2009). Pulled over: How police stops define race and citizenship. Chicago, IL: University of Chicago Press. 
Equality Human Rights Commission, UK. (2012). Race disproportionality in stops and searches under Section 60 of the Criminal Justice and Public Order Act 1994. Available at https://www.equalityhumanrights.com

Fanon, F. (1967). Wretched of the earth. New York, NY: Grove Press.

Fearon, G., \& Farrell, C. 2019. Perceptions of the Toronto police and impact of rule changes under regulation 58/16: A community survey. Available at http://tpsb.ca.

Ferrell, J., Hayward, K., Morrison, W., \& Presdee, M. (Eds.) (2004). Cultural criminology unleashed. London, UK: GlassHouse.

Foster, L., Jacobs, J., \& Siu, B. (2016). Race data and traffic stops in Ottawa, 2013-2015: A report on Ottawa and the police districts submitted to Ottawa Police Services Board and Ottawa Police Service. Available at https://www.ottawapolice.ca.

Gabor, T. (2004) Inflammatory rhetoric on racial profiling can undermine police services. Canadian Journal of Criminology and Criminal Justice, 45(3), 457-466.

Gabor, T. (1994). The suppression of crime statistics on race and ethnicity: The price of political correctness. Canadian Journal of Criminology, 36(2), 153-163.

Galtung, J. (1969). Violence, peace, and peace research. Journal of Peace Research, 6, 167-191.

Gilroy, P. (1987). The myth of Black criminality. In P. Scraton (Ed.) Law, order, and the authoritarian state: Readings in critical criminology (pp. 47-56). Milton Keynes, UK: Open University Press.

Gold, A. (2003). Media hype, racial profiling, and good science. Canadian Journal of Criminology and Criminal Justice, 45(3), 391-399.

Gross, S. (2007). The rhetoric of racial profiling. In R. L. Weiner, B. H. Bornstein, R. Schopp \& S. L. Willborn (Eds.) Social consciousness in legal decision making: Psychological perspectives (pp. 35-60). New York, NY: Springer.

Guarino, M. (2013, September 16). Chicago Mayor Rahm Emanuel apologizes for two decades of police torture. Christian Science Monitor. Available at https://www.csmonitor.com.

Glassbeek, H. (2012). Wealth by stealth: Corporate crime, corporate law, and the perversion of democracy. Toronto, Canada: Between the Lines. 
Hadden, S. E. (2001). Slave patrols: Law and violence in Virginia and the Carolinas. Cambridge, MA: Harvard University Press.

Harcourt, B. E. (2006). Against prediction: Profiling, policing, and punishing in an actuarial age. Chicago, IL: University of Chicago Press.

Harris, D. A. (2003). Profiles in injustice: Why racial profiling cannot work. New York, NY: The New Press.

Hartman, S. (1997). Scenes of subjection: Terror, slavery, and self-making in nineteenth-century America. New York, NY: Oxford University Press.

Harvard Law Review Association (1988). Developments in the law: Race and the criminal process. Harvard Law Review, 101(7), 1472-1641.

Hayle, S., Wortley, S., \& Tanner, J. (2016). Race, street life, and policing: Implications for racial profiling. Canadian Journal of Criminology and Criminal Justice, 58(3), 322-353.

Hawkins, H., \& Thomas, R. (1991). White policing of Black populations: A history of race and social control in America. In E. Cashmore \& E. McLaughlin (Eds.) Out of order: Policing Black people (pp. 65-86). London, UK: Routledge.

Hepburn, J. (1978). Social control and the legal order: Legitimated repression in a capitalist state. In W. K. Greenaway \& S. L. Brickey (Eds.) Law and social control in Canada. Scarborough: Prentice-Hall.

Hillyard, P., \& Tombs, S. (2004). Beyond criminology? In P. Hillyard, C. Pantazis, S. Tombs \& D. Gordon (Eds.) Beyond criminology: Taking harm seriously (pp. 10-29). London, UK: Pluto Press.

Hirschi, T. (1993). Administrative criminology. Contemporary Sociology, 22(3), 348-350.

Hochschild, A. (1998). King Leopold's ghost: A story of greed, terror, and heroism in colonial Africa. Boston, MA: Houghton Mifflin.

Hulsman, L. (1986). Critical criminology and the concept of crime. Contemporary Crises, 10, 63-80.

Institute on Race and Justice, North Eastern University (n.d.). Reports. Available at https://www.northeastern.edu.

Juarez, J. (2004). Brotherhood of corruption: A cop breaks the silence on police abuse, brutality, and racial profiling. Chicago, IL: Chicago Review Press.

Kitossa, T. (in review). Exporting epistemic necropolitics: On intellectual marronage and why the 'Global South' should be wary of 
criminologists bearing gifts. Social Transformations - Journal of the Global South.

Kitossa, T. (2014). Authoritarian criminology and the racial profiling debate in Canada: Scientism as epistemic violence. African Journal of Criminology and Justice Studies, 8(1), 63-88.

Kitossa, T. (2005). Malleus Maleficarum Africanus: The criminalization of African Canadians and 'due process' as a property of whiteness. In L. Visano (Ed.) Law and criminal justice: A critical inquiry (pp. 153171). Toronto, Canada: APF.

Kittrie, N. (1973). The right to be different: Deviance and enforced therapy. Baltimore, MD: Penguin.

Lamberth, J. (2006). Data collection and benchmarking of the bias policing project: Report for the Metropolitan Police Department in the District of Columbia. Available at https://mpdc.dc.gov.

Levin, M. (1992). Responses to race differences in crime. Journal of Social Philosophy, 23(1), 5-29.

Lynch, M. (2000). The power of oppression: Understanding criminology as the science of oppression. Critical Criminology, 9(1/2), 146-152.

Lundberg, F. (1973). The rich and the super-rich: A study in the power of money today. London, UK: Bantam Books.

MacDonald, H. (2015a). The myth of criminal-justice racism. City Journal. Available at http://www.city-journal.org.

MacDonald, H. (2015b, November 29). When police back off, streets get mean. Providence Journal. Available at http://www.manhattaninstitute.org

MacDonald, H. (2001). The myth of racial profiling. City Journal. Available at https://www.city-journal.org.

Mann, C. (1993). Unequal justice: A question of color. Indianapolis, IN: Indiana University Press.

Mann, C. (1995). The contribution of institutionalized racism to minority crime. In D. Hawkins (Ed.) Ethnicity, race and crime: Perspectives across time and place (pp. 259-280). New York, NY: State University of New York Press.

Mathiesen, T. (1990). Prison on trial: A critical assessment. London, UK: Sage.

Marx, K. (1978). The Marx Engels Reader (2nd Ed.). New York, NY: W. W. Norton. 
Melchers, R. (2006, September 9). Inequality before the law: The Canadian experience of 'racial profiling'. Ottawa, ON: Royal Canadian Mounted Police. Available at http://publications.gc.ca.

Melchers, R. (2003). Do Toronto police engage in racial profiling? Canadian Journal of Criminology and Criminal Justice, 45(3), 347-365.

Mills, C. W. (2000). The sociological imagination. New York, NY: Oxford University Press.

McIntyre, C. (1993). Criminalizing a race: Free Blacks during slavery. Queens, NY: Kayode Publications.

Moreton-Robinson, A. (2009). Imagining the good Indigenous citizen: Race war and the pathology of patriarchal White sovereignty. Cultural Studies Review, 15(2), 61-79.

Muhammad, K. G. (2010). The condemnation of Blackness: Race, crime, and the making of modern urban America. Cambridge, MA: Harvard University Press.

Nicolaus, M. (1969). The professional organization of sociology: A view from below. The Antioch Review, 29(3), 375-387.

Nova Scotia Human Rights Commission (2019). Halifax, Nova Scotia: Street checks report. Available at https://humanrights.novascotia.ca.

Ontario Association of Chiefs of Police (2001). Review of proposed police performance measurements. Available at http://www.oacp.on.ca.

Ontario Human Rights Commission (2018). A collective impact: Interim report on the inquiry into racial profiling and racial discrimination of Black persons by the Toronto Police Service. Available at http://www.ohrc.on.ca.

Ontario Human Rights Commission (2017). Under suspicion: Research and consultation report on racial profiling in Ontario. Available at http://www.ohrc.on.ca.

Parenti, C. (2003). The soft cage: Surveillance in America from slavery to the war on terror. New York, NY: Basic Books.

Pepinsky, H. (1982). Introduction. In H. Pepinksky (Ed.) Rethinking crimiology. Beverly Hills, CA: Sage.

Quebec Human Rights Commission. (2011). Racial profiling and systemic discrimination of racialized youth. Available at http://www.cdpdj.qc.ca. 
Reasons, C. E. (1974). Race, crime and the criminologist. In C. Reasons (Ed.) The criminologist: Crime and the criminal (pp. 89-97). Pacific Palisades, CA: Goodyear Publishing.

Reiman, J., \& Leighton, P. (2017). The rich get richer and the poor get prison: Ideology, class, and criminal justice (11th ed). Boston, MA: Allyn \& Bacon.

Roberts, D. (2011). Fatal invention: How science, politics, and big business re-create race in the twenty-first century. London, UK: The New Press.

Roberts, D. (1993). Crime, race and reproduction. Tulane Law Review, 67, 1945-1977.

Roberts, J. (2003). Introduction: Commentaries on policing in Toronto, Canadian Journal of Criminology and Criminal Justice, 45(3), 343346.

Roberts, J. (1994). Crime and race statistics: Toward a Canadian solution. Canadian Journal of Criminology, 36(2), 175-185.

Rodney, W. (1982). How Europe underdeveloped Africa. Washington, D.C.: Howard University Press.

Rocque, M., \& Posick, C. (2017). Paradigm shift or normal science? The future of (biosocial) criminology. Theoretical Criminology, 21(3), 288303.

Ryan, W. (1971). Blaming the victim. New York, NY: Pantheon Books.

Said, E. (1993). Representations of the intellectual. New York, NY: Vintage Books.

Saleh-Hanna, V. (2015). Black feminist hauntology: Rememory the ghosts of abolition? Abolitionnisme - Abolitionism, XII. Available at https://journals.openedition.org.

Satzewich, V., \& Shaffir, B. (2009). Racism versus professionalism: Claims and counter-claims about racial profiling. The Canadian Journal of Criminology and Criminal Justice, 51(2), 199-226.

Schwendinger, H., \& Schwendinger, H. (1970). Defenders of order or guardians of human rights? Issues in Criminology, 5(2), 123-157.

Sellin, T. (1935). Race prejudice in the administration of justice. American Journal of Sociology, 41(2), 212-217.

Scott, J. C. (2017). Against the grain: A deep history of the earliest states. London, UK: Yale University Press.

Scott, J. C. (1998). Seeing like a state: How certain schemes to improve the human condition have failed. London, UK: Yale University Press. 
Scott, J. C. (1985). Weapons of the weak: Everyday forms of peasant resistance. London, UK: Yale University Press.

Shapin, S., \& Schaffer, S. (1985). Leviathan and the air-pump: Hobbes, Boyle and the experimental life. Princeton, NJ: Princeton University Press.

Simon, J. (2006). Governing through crime: How the war on crime transformed American democracy and created a culture of fear. New York, NY: Oxford University Press.

Stamper, N. (2005). Breaking rank: A top cop's exposé of the dark side of American policing. New York, NY: Nation Books.

Stannard, D. (1992). American holocaust. The conquest of the New World. New York, NY: Oxford University Press.

Staples, R. (1975). White racism, Black crime, and American justice: An application of the colonial model to explain crime and race. Phylon, 3(1), 14-22.

Stewart, G. (1998). Black codes and broken windows: The legacy of racial hegemony in anti-gang civil injunctions. The Yale Law Journal, 107(7), 2249-2279.

Sutherland, E., \& Cressey, D. (1955). Principles of criminology (5th ed). New York, NY: M. B. Lippincott.

Tator, C., \& Henry, F. (2006). Racial profiling in Canada: Challenging the myth of a few bad apples. London, UK: University of Toronto Press.

Tanovich, D. (2006). The colour of justice: Policing race in Canada. Toronto, ON: Irwin Law.

Tanovich, D. (2004). E-racing racial profiling. Alberta Law Review, 41(4), 905-933.

Tauri, J. (2012). Criminal justice as a colonial project in contemporary settler colonialism. African Journal of Criminology and Justice Studies, 8(1), 20-37.

Tauri, J. (2012). Indigenous critique of authoritarian criminology. In K. Carrington, M. Ball, E. O’Brien, \& J. Tauri (Eds.), Crime, justice and social democracy: International perspectives (pp. 217-233). London, UK: Palgrave MacMillan.

Tilly, C. (1985). War making and state making as organized crime. In: P. B. Evans, D. Rueschemeyer, \& T. Skocpol (Eds.) Bringing the state back in (pp. 167-191). Cambridge, UK: Cambridge University Press. 
Rankin, J., \& Winsa, P. (2013, September 27). One officer, five years, 6,600 contact cards. Toronto Star. Available at http://www.thestar.com.

Rankin, J. (2002). Singled out. Toronto Star. Available at http://www.thestar.com.

Rankin, J., \& Winsa, P. (2013, September 27). As criticism piles up, so do the police cards. Toronto Star. Available at http://www.thestar.com.

Tulloch, M. (2018). Report of the independent street checks review. Government of Ontario. Available at https://www.mcscs.jus.gov.on.ca.

Washington, H. (2006). Medical apartheid: The dark history of medical experimentation on Black Americans from colonial times to the present. New York, NY: Doubleday.

Willhelm, S. (1971). Who needs the negro? New York, NY: Doubleday books. Willis-Esqueda, C. (2007). Racial profiling as a minority issue. In R. L. Weiner, B. H. Bornstein, R. Schopp, \& S. L. Willborn (Eds.) Social consciousness in legal decision making: Psychological perspectives (pp. 75-87). New York, NY: Springer.

Wortley, S. (2006). Bias-free policing: The Kingston data collection project: Final results. Available at https://qspace.library.queensu.ca.

\section{Endnotes}

1 In its exposure of racial 'disproportionality' in the 'carding' of African Canadians the Toronto Star reports that “...\#81499756 received credits on 6,600 contact cards from 2008 to 2012, the second highest count of all officers" (Rankin \& Winsa, 2013). Rankin and Winsa note also that “...black people represent 8.1 per cent of the city's population, 58 per cent of the officer's cards involved blacks" (Idid). Such 'data' constitutes clear evidence that the statistics which are taken as prima facie evidence of Black criminality are in fact contrived by personal and organizational motivations. Facing considerable political pressure from community groups, both the provincial government of former premier, Kathleen Wynne, the current mayor of Toronto, John Tory, were compelled to respectively conduct wide-ranging judicial-led public inquiries (Tulloch, 2018) and demand that the Toronto police board limit the practice to justifiable rationales. Because the Metro-Toronto police faced the mounting loss of consent from communities disproportionately targeted for 'carding' 
commissioned, the Metro-Toronto Police Services Board commissioned its own (face-saving) public inquiry. From the vantage of a realist interpretation of the hardware of statecraft, the most remarkable but unsurprising result of this inquiry is the toxic nature of contact with the police as opposed to the perception of those that have had no contact with the police. Evidence that contact with the police is more often than not a toxic encounter, a significant proportion of 'carded' persons held a decidedly negative view of the police. Probably not surprising is that African Canadians, as opposed to other racial groups, had consistently negative views of the police (Metro-Toronto Police Services Board, 2019). In the UK and US, Dorothy Roberts (2011) reports that in addition to routine law enforcement activities such as 'carding' and racial profiling are vital to the genetic documentation of African descended people: in the UK " $40 \%$ of all black men and $77 \%$ of black men ages fifteen to thirty-five, compared with only 6 percent of white men, were estimated to have genetic profiles in the UK national DNA database in 2006...[While in the US] in 2006...at least 40 percent of the genetic profiles in the U.S. federal database were from African Americans [who are]...13 percent of the national population" (Roberts, 2011, pp. 277-78).

2 A range of scholars have demonstrated that the determinisms of biology, culture, psychology and socio-economy, singly or in some combination, are the foundational basis for criminology, despite manifest and largely surface differences (Kittrie, 1973; Mann, 1993; Pepinsky, 1982; Reasons, 1974).

3 I do not use this term in any way that is hyperbolic. Here is the logic of a Canadian judge affirming the point: "In light of six years of rhetoric and jurisprudence about the Charter, some Canadians may shudder to realize that the security needs of a free and democratic society are, in a few basic essentials, much the same as those which totalitarian societies arrogate unto themselves. Utter secrecy, subject to certain checks, in security intelligence matters is one. That necessary degree of secrecy is so much more fissiparous in freedom and democracy than it is under the stifling oppression of a totalitarian régime, and it is therefore objectively justifiable in terms of paragraph 46(1)(b) of the Privacy Act. What no doubt distinguishes this free and democratic society from those which are less or not at all so, are the right to apply for, and obtain the results of, the Privacy Commissioner's investigation, and the right to apply to this Court 
for a review" (Zanganeh v. Canadian Security Intelligence Service, 1989, para. 12).

4 I invoke Hannah Arendt with caution and reservation. The anti-Blackness that suffuses her work, especially On Violence (1970), raises questions about her ethical authenticity. 